\title{
Grappling with rabbinic literature
}

\section{Book Title:}

The literature of the Sages. Second Part: Midrash and Targum, liturgy, poetry, mysticism, contracts, inscriptions, ancient science and the languages of Rabbinic Literature

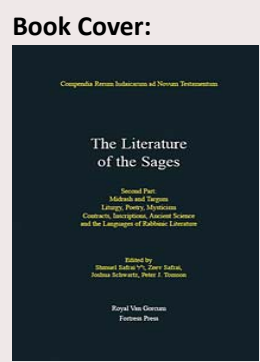

Editors:

Shmuel Safrai, Zeev Safrai, Joshua Schwartz \& Peter J. Tomson

ISBN:

9780800606060

Publisher:

Royal van Gorcum, Assen, 2006, p. 772, \$49.77*

*Book price at time of Review $\square$

Review Title: Grappling with rabbinic literature

Reviewer:

Pieter M. Venter ${ }^{1}$

Affiliation:

${ }^{1}$ Department of Old

Testament Studies,

University of Pretoria,

South Africa

Email:

pm.venter@up.ac.za

Postal address:

PO Box 914-1530, Wingate

Park 0153, South Africa
C 2011. The Authors. Licensee: AOSIS OpenJournals. This work is licensed under the Creative Commons Attribution License.
The aim of the Compendia Rerum Judaicarum ad Novum Testamentum is to present a detailed picture of rabbinic literature, thereby introducing the reader to the cultural and ideological background of the New Testament world. The Compendia comprise two sections. The two volumes belonging to Section One, published in 1974 and 1976 respectively, explore the history and social culture of Judaism in the period of the formation of the New Testament. Section Two is titled, The Literature of the Jewish People in the Period of the Second Temple and the Talmud. This section consists of four volumes. The first volume (Mikra, published 1988) deals with the text, translation, reading and interpretation of the Hebrew Bible in ancient Judaism and early Christianity. The second volume (Jewish Writings of the Second Temple Period, published 1984) is dedicated to literature of this period that was not included in the Hebrew Bible. Volumes three and four deal with the literature of the Sages of classical rabbinic Judaism. The third volume (published 1987) addresses oral Torah, Halakha, Mishna, Tosefta and Talmud. The fourth volume, discussed here, was published in 2006. This volume concluded the Compendia Foundation's project, dealing with categories not addressed in the third volume: midrash, aggada, targum, liturgical texts and a number of auxiliary subjects.

During his lifetime, the author Shmuel Safrai propagated the opinion that the background to the New Testament is to be found in ancient Judaism, especially in the literature of the Sages. This then also forms the thrust of the volume under discussion. The endeavor to indicate the relevance of the literature of the Sages and its underlying traditions for the world of the New Testament is however, not without its methodological and literary problems, as can be seen in the varying approaches found in this volume.

This voluminous publication consists of 20 contributions by 18 experts and is divided into four sections. The five chapters forming the first section are related to the contents of the third volume of Section Two of the Compendia. This section deals with central documents of rabbinic Judaism. Discussing halakhic and aggadic Midrash and extant Targums in great detail, these chapters analyse the contents, problems of textual criticism, specific nature and research into this specific literature. In the six contributions that constitute the second section, the authors discuss literature relevant to the New Testament, such as liturgies (prayers, the Passover Haggada, Scroll of Fasting, Piyyut), poems and mystical esoteric texts, describing visionary experiences and magic ritual. The six chapters in Section three deal with contracts, inscriptions and ancient science. The first two chapters pay attention to contracts in rabbinic literature and in ancient Jewish documents, as well as Jewish inscriptions. Medical interests, cosmography, biology and even occult knowledge of divination and astrology are discussed in the following four chapters as part of the world of the Sages' knowledge. The last section does not deal with documents as such, but rather with the language used in them. Three chapters discuss Mishnaic Hebrew, Aramaic of the Talmudic period, and rabbinic knowledge of Greek.

Finally, the work includes a list of abbreviations (pp. 641-644), an extensive bibliography (pp. 645-710), indices (pp. 711-748) referring to sources such as the Hebrew Bible, Qumran Scrolls, Palestinian and Babylonian Talmuds etcetera, and a list of personal names (pp. 749-772).

As Jesus' Jewishness has recently become very prominent in Christian research, this publication is of great importance. It gives us a well balanced and thoroughly researched vision on the world of Judaism during the lifetime of Christ. It is well organised, presenting an outline of its contents at the start of each contribution and it concludes with a useful list of literature for further reading. It is highly recommended for scholars and advanced students working in this field.

How to cite this book review: Venter, P.M., 2011, ‘Grappling with rabbinic literature’, HTS Teologiese Studies/Theological Studies 67(3), Art. \#1141, 1 page. http://dx.doi.org/10.4102/hts.v67i3.1141 